\title{
Kernos
}

Revue internationale et pluridisciplinaire de religion grecque antique

$20 \mid 2007$

Varia

\section{CURRIE Bruno, Pindar and the Cult of Heroes}

\section{Gunnel Ekroth}

\section{(2) OpenEdition}

\section{Journals}

Electronic version

URL: https://journals.openedition.org/kernos/356

DOI: 10.4000/kernos.356

ISSN: 2034-7871

Publisher

Centre international d'étude de la religion grecque antique

Printed version

Date of publication: 1 January 2007

Number of pages: 420-425

ISSN: 0776-3824

\section{Electronic reference}

Gunnel Ekroth, "currie Bruno, Pindar and the Cult of Heroes", Kernos [Online], 20 | 2007, Online since 17 March 2011, connection on 08 September 2022. URL: http://journals.openedition.org/kernos/356 ;

DOI: https://doi.org/10.4000/kernos.356

All rights reserved 
deux sanctuaires de l'Ourania athénienne localisés respectivement au sud-est et au nord-ouest de la cité, auraient inscrit dans le calendrier athénien les phases de la constellation Capella (anciennement la «Chèvre », les « Chevreaux » ou le «Cocher »), dont le lien avec Aphrodite expliquerait l'épiclèse céleste de la déesse.

Le lien entre les espaces publics d'Athènes et les traditions mythiques qui leur sont rattachées est également au centre de l'étude de J.-M. Luce, qui analyse en particulier les cultes et les mythes impliquant l'Acropole et les premiers rois d'Athènes. L'A. lit la topographie de la cité à l'aide de son histoire religieuse et politique : l'Acropole est le passé, où la ville fonde son ancienneté en se rattachant à une royauté mythique placée sous le signe de Poséidon et d'Athéna; l'ancienne agora, à l'est de l'acropole, est la ville basse de Thésée, le « héros-roi» du synécisme, et y résident en effet les institutions politiques de l'Attique tout entière; enfin, dans la nouvelle agora du Céramique, la présence emblématique des Tyrannoctones célèbre l'espace du régime démocratique. P. Carlier consacre son étude à une analyse attentive de la liste des rois d'Athènes : il montre bien qu'il s'agit d'une construction historique assez ancienne, qui continue néanmoins de se modifier encore à l'époque des Atthidographes. Traditions orales et traditions écrites coopèrent dans cette reconstruction du passé qui fonde l'identité de la communauté : ainsi, à travers la succession de rois primordiaux, puis d'une dynastie héroïque, enfin d'une nouvelle dynastie entrainant la chute de la royauté, cette liste raconte bien l'histoire des origines d'Athènes et de ses institutions politiques. C'est au demeurant par une réflexion sur le rapport entre mythe et histoire que J. Scheid conclut le volume: en dressant le bilan de cette enquête comparatiste autour d'Athènes et de Rome, il signale à juste titre que l'historien engagé dans une recherche sur les origines, dans la mesure où il se trouve souvent confronté à des récits mythiques, ne peut éluder le problème méthodologique posé par ce type de sources, car il s'agit d'une documentation qui nécessite d'être lue et étudiée dans sa spécificité.

Même s'il ne relève qu'en partie le défi d'une démarche comparatiste, cet ouvrage se signale par des apports originaux qui contribuent à renouveler le débat sur les origines des deux cités. Les réflexions sur la formation des espaces publics, question fondamentale pour comprendre les premières phases d'Athènes et de Rome, constituent l'intérêt de ce volume, d'autant plus que les diverses contributions offrent à ce sujet un éventail de perspectives différentes. Il n'en reste pas moins que, dans certaines des ces études, des problèmes de méthode se laissent cerner: la faible problématique religieuse, alors que la religion est souvent appelée à la barre, la négligence de la spécificité de ces récits traditionnels qu’on appelait autrefois «mythes » et, surtout, l'utilisation de sources prétendument historiques qui pourraient bien se révéler, au terme d'une analyse rigoureuse, tout aussi «mythiques » que les « mythes »...

Gabriella Pironti

(Centre Louis Gernet, EHESS - Paris)

CurRie Bruno, Pindar and the Cult of Heroes, Oxford, Oxford University Press, 2005. 1 vol. $14 \times 22 \mathrm{~cm}$, XIV+487 p. (Oxford Classical Monographs). ISBN : 0-19927724-9.

Contrary to what one might assume from the title, this is not a book about hero-cult in Pindar, but an investigation of the extent to which the commissioners of Pindar's epinicians were heroized. Pindar's epinician poetry and the cult of heroes are therefore pursued independently as well as jointly throughout the study, in order to explore the link between the heroes honoured in Pindar and actual hero-cults. Among the paradigms of our modern view of Greek hero-cults is the notion that to receive a hero-cult, a person had to be dead. Bruno Currie challenges this idea by arguing that fifth-century communities treated living 
persons in a manner containing religious elements and sometimes even extended these honours into a full-blown hero-cult. Furthermore, many ancient Greeks, especially the famous and accomplished, took an active interest in their fate after death, taking initiatives to promote their own posthumous hero-cults already in their lifetime. We therefore should question the view that in the Classical period, all honours paid to a person in his lifetime were purely secular and that a hero-cult was necessarily a cult of a dead person.

The book originated as a doctoral thesis written in Oxford but has been substantially expanded. The theme of Pindar and hero-cults has not exactly been popular among scholars: the last monograph on the topic was published in 1865 (C. Ohlert, De heroologia Pindarica). The Introduction (Ch. 1) presents the aims of the book and the author's views on heroization, the relationship between the living and the heroes as well as between hero-cult and ruler cult. Here one would have liked to have been given a definition of what, according to $\mathrm{C}$ (urrie), constitutes a hero-cult, since this is not self-evident and there is no ancient, clear-cut classification to fall back on. Furthermore, as one of the aims of the book is to explore the possibility that hero-cult could also be performed to historical persons, it would have been useful to see how C. perceives hero-cult to be different from the cult of the ordinary dead, both as to principle and in practice. Such considerations are important for the interpretation of the written sources. In the same chapter, the author also takes a stand on a number of methodological questions concerning Pindar, stressing the importance of interpreting Pindar's poems both in the light of the epinician corpus itself and evidence independent of Pindar's texts, since a comparison to the ancient cultural context is essential for a proper understanding of the odes. C. also discusses when and how the odes were performed (arguing for a public aspect of all occasions for performance), the definition of an epinician and the difficulties to date the odes.

Part I consists of five short chapters, which treat different aspects of heroes and herocults and Pindar's treatment of these, particularly in comparison with Homer, since this is indispensable for the understanding of Pindar. Discussed here are the views of death (Ch. 2), mortality and immortality (Ch. 3), hero-cult as a religious phenomenon (Ch. 4), the uses of the word heros (Ch. 5) and the concept of kleos (Ch. 6). In all, Pindar is considered to represent a view of death, heroes and heroization, which is different from that found in Homer. The origins of hero-cult are not considered but there is an interesting discussion of the uses of the term heros, which brings out its complexities and demonstrates that the commonly evoked contrast between "heroes of cult" and "heroes of epic" is a scholarly product rather than an accurate reflection of the ancient evidence. C. emphasizes the importance of a beros as a recipient of cult in all uses of the term, even when it is applied to the living.

Part II addresses heroizations in the 5th century BC. As the heroization of historical persons has not been systematically studied previously he chooses to focus on three aspects: the war dead, athletes and religious attitudes to the living. Whether the war dead (Ch. 7) are to be considered as heroes or not has been disputed by scholars, since the contemporary sources do not call them heroes. C. looks at the wider context of the treatment and nature of the war dead and convincingly argues that they must have been object for hero-cults. The heroization of athletes (Ch. 8) is less controversial and Pindar, in a fragment (fr. 133), explicitly states that 'men swift in strength' were among those to be called 'holy heroes' for the rest of time. It has often been assumed that these individuals were heroized for political reasons but their athletic accomplishments must in fact have been central to them being given this status. The legends surrounding the athletes often show typical heroic characteristics, such as divine birth and extraordinary feats and deaths. The treatment of the victorious athletes also bordered on heroization: processions, special clothing, garlands, statues as well as victory odes taking over features from the hymns for the gods. Posthumous hero-cult of 
athletes therefore naturally followed the treatment they were given while still alive. The institution of a hero-cult was a decision, which had to be taken by the community and not all athletes happened to find themselves a political and social context, which would undertake such an action, though many more athletes were probably recipients of hero-cults than what has been realized previously.

The final chapter of Part II considers the theios aner, an ancient designation for a godlike man, who was regarded as more than human. These persons, among whom the athletes are to be included, could be presented with extravagant public 'receptions' and have prayers addressed to them, both actions that recognize their divine status and entitlement to cult. A number of persons receiving honours like a god or a hero are reviewed in detail, for example Lysandros, Brasidas and Gelon, suggesting that the concepts of Hellenistic ruler cults can be traced back to the 5 th century. C. here tries to separate the concept heros from the notion of death and deadness in order to demonstrate that heroic honours, as well as cult honours in a wider sense, were not incompatible with the recipient being alive. It is too simple to see all honours to a living person as secular and all religious honours as posthumous and instead C. wishes to blur the categories by arguing that the evidence shows that a number of people, especially athletes, aspired to become heroes and that the honours they were shown in their lifetime anticipates posthumous hero-cult. This is the context in which the victory odes have to be fitted.

Though the book states its concern with both religion and Greek poetry, it appears foremost as a study of Pindar. Parts I and II serve as a kind of preliminary, which constantly looks forward to the essential part of the investigation, Part III, the analysis of five of Pindar's victory odes (Ch. 10-14). Four of the odes chosen are such in which the laudandus, the person celebrated, is compared to a mythical hero receiving cult or to a dead relative who apparently was heroized, while the fifth, Pythian 3, approaches the subject of immortality in a different manner.

In Isthmian 7 (Ch. 10), the laudandus is Strepsiades, a pankration victor from Thebes who is compared to his uncle and namesake, who was killed in battle. The language used to describe Strepsiades the elder indicates that he was the object of a cult in Thebes, together with other war dead and recently departed persons. Strepsiades and his uncle are further presented as continuing a long line of Theban heroes, in the same manner as the Athenian funeral orations compare mythic and modern exploits and deeds. C. conducts a detailed discussion of Pindar's language, use of verbal echoes and terminology in order to elucidate the religious sense and action behind the words. The conclusion is that Strepsiades is presented in such a way and in such a context that a hero-cult is hinted at, even though not explicitly pronounced.

Pythian 5, analyzed in Ch. 11, was commissioned by Arkesilas IV, king of Kyrene, after a chariot victory, and probably performed at the Karneia in the same city. The hero-cult focused on in this ode is that of Battos, the founder of Kyrene, who definitely received a hero-cult after his death. The Battiad kings also seem to have been recipients of cult, judging by how they are described by Pindar. Verbal echoes in the descriptions of the Battiad kings and Battos, on the one hand, and in the passages regarding their descendant Arkesilas, on the other, establish their close relationship. Since Battos is described by Pindar as 'blessed' and having an exceptional status in his lifetime, as well as receiving a hero-cult after death, we are to assume that this ode, which presents Arkesilas as blessed in life, also must be taken as an indication of him being posthumously heroized. The hints of hero-cult for Arkesilas in Pythian 5 are further suggested to have been politically motivated, justifying his right to rule by emphasizing his special status. 
Chapter 12 discusses Hieron of Syracuse and Pythian 2, an ode celebrating a chariot victory, which probably took place in Thebes. The heroic parallel evoked in the ode is that between Hieron and Kinyras, a Cypriot hero, presumably worshipped at Paphos. The link between these two is established by a highly intricate and partly also speculative chain of arguments using a number of different sources, some of which are very late (Johannes Lydos of the 6th century AD) or refer to cults both geographically and ritually removed from Greek religion of the Classical period (Phoenician Byblos). Both Hieron and Kinyras have a special connection to cults of Aphrodite, which demonstrate certain traits, such as sacred prostitution and ram sacrifices, which may fall back on real similarities in cult practice at Lokris and Paphos, respectively.

Hieron's relation to Lokris is fundamental for the understanding of the ode, his link to Kinyras and his heroic status. Hieron intervened to defend Lokris from being destroyed by Rhegion, an action, which led to him being honoured at Lokris by girls' choruses at the festival of Aphrodite. At the same festival, the Lokrian girls may have prostituted themselves as part of a vow made during the conflict with Rhegion. The question of sacred prostitution at Lokris has been hotly debated and C., after a detailed scrutiny of the evidence, written as well as archaeological, concludes that sacred prostitution probably did take place at Lokris although the evidence is controversial. The principal reason for claiming heroic status for Hieron is, however, to be linked to his role as a saviour of Lokris. Though cults of saviours became formalized in the 4th-3rd centuries, Pindar clearly employs the vocabulary of such cults in his account, an indication of religious attitudes to saviours existing already in the early Classical period. C. proposes a reorganization of Aphrodite's cult at Lokris and the establishment of a new festival, the Soteria, at which Hieron as a soter was integrated with the cult of the goddess.

The fourth ode to be analyzed, Nemean 7 (Ch. 13), concerns the young pentathlete Sogenes from Aegina, linked to Neoptolemos who was buried at Delphi. A cult of Neoptolemos at this sanctuary has been disputed before the 3rd century BC but C. argues for him being worshipped already in the Classical period. The handling of the complex archaeological evidence for a cult of Neoptolemos at Delphi is not entirely convincing and C. here seems to have regarded any ash found in a sanctuary as the remains of sacrifices, no matter the period or context. ${ }^{1}$ Though we know nothing of the religious fate of Sogenes at a later period, the story of Neoptolemos being buried and worshipped at Delphi may be taken as an indication of hero-cult also being a prospect for Sogenes.

The account of Neoptolemos in Nemean 7 has all since antiquity been linked to Paean 6, in which Pindar gave an allegedly unflattering account of Neoptolemos, which is thought to have angered the Aeginetans who commissioned the paean, and prompted Pindar to apologize by presenting a different version in Nemean 7. C. dissects the arguments in favour of the so-called 'Apology theory' showing how it is largely based on assumptions about the ode's date and its reception by the ancient audience, as well as conjectures about Pindar's own character and person, and is therefore to be dismissed. Instead, he proposes that the link between Nemean 7 and Paean 6 consists of them both treating Delphic myth. The relevance of Delphi for Aegina is suggested to be the Delphic ritual of Theoxenia, to which a delegation was sent from Aegina. C. conducts an interesting discussion using written and archaeological evidence to support his suggestion that Nemean 7 may have been performed before the Aeginetan delegation left for Delphi, in connection with sacrifices and feasting in which

\footnotetext{
${ }^{1}$ For the identification of Neoptolemos' cult place, see also S. FUnKE, Aiakidenmythos und epirotisches Königtum. Der Weg einer hellenistischen Monarchie, Stuttgart, 2000, p. 87-94.
} 
Sogenes' father was involved, thus also strengthening the relevance of the connection between Neoptolemos and Sogenes.

The final ode (Ch. 14) is Pythian 3, composed for Hieron on account of his bad health rather than of an athletic victory. Among scholars, this ode has been seen as most clearly showing how Pindar rejects the idea of a literal immortality for Hieron and instead forcefully claims that the only possibility for immortality lies in song. C., however, argues that the ode's principal concern is with various themes of literal immortality.

He proposes that the main topic of Pythian 3 is fire and how fire can both kill and preserve, and even render a heroic or immortal status. Some of the mythological characters presented in the beginning of the ode, Asklepios, Koronis, Semele and Achilles, became immortal after having been killed by a thunderbolt or burnt on a funeral pyre. That also historical figures could be transformed in the same manner is demonstrated by the detailed review of a number of such persons who were immortalized, or at least commemorated, after death by fire or after having been cremated. The suggestion that cremation would lead to a particular status after death is problematic, however. Considering that cremation was a widespread burial method in antiquity it can hardly automatically be linked to any concept of immortality. The cremated persons who received a particular status after death seem to have been given that due to who they were before dying, rather than by this particular burial mode having been chosen.

Finally, Pythian 3 is placed within the wider context of the historical and personal situation of Hieron, especially his role as a hierophant at the mysteries of Demeter and Kore at Syracuse. The eschatological possibilities offered by the mysteries are explored and here Hieron's personal involvement in a mystery cult is linked to Pindar's connection with the cult of the Mother in Thebes, which would explain why Pindar directs a prayer to this divinity in the middle of the ode.

The last chapter, entitled Epilogue, constitutes a clear summary of the arguments presented and also addresses the question that easily springs to the reader's mind: if, in the Classical period, heroization was more commonly practiced than what has been thought previously, and if heroic honours could even be presented to persons still living, who also promoted the installation of such cults for themselves, why is Pindar so discrete in referring to these practices? C. states that inexplicitness is a hallmark of the Pindaric epinician but, most of all, that the social and aesthetic context of the victory odes demanded the poet to be subtle and indirect. The allusive manner in which the claims for hero-cult are presented also allowed the laudator to navigate between those who would be hostile to the commissioner's exceptional status and those who would welcome it.

The book finishes with an extensive bibliography, which is appreciated, since this is not the case with all volumes issued by the Oxford University Press. There is one index of the main passages discussed, as well as a short general index. The text is illustrated with plans of Kyrene, Lokris, Delphi and Aegina. Almost all Greek is translated, which is welcome, considering the difficulties inherent in Pindar's language. One misprint (there are very few), which might cause confusion for the reader not familiar with the topography of Delphi, is p. 297, n. 4, where the reference to Fig. 3, no. 19 should be to no. 20, and Fig. 3, no. 16 to no. 17 (the same mistake repeated on p. 300, n. 21).

C.'s study is stimulating, well-argued and exemplarily well-organized, with the ancient evidence laid out in a full manner, which makes the often complex discussions easy to follow. The book clearly exposes the shaky ground on which rest many deductions about the meaning and intents of Pindar himself and his commissioners. The continuous effort to try to connect the rhetorics of the odes to any evidence for actual cult of the persons honoured is interesting though the argument sometimes becomes incredibly complex and 
somewhat strained when trying to match the two categories. The evidence used to elucidate Pindar and the persons whom the odes honour is drawn from a wide variety of sources as to date and character. In view of some of these authors being substantially later than Pindar, a consideration of the methodological implications of such a wide use would have been appropriate. For example, the conclusion that Neoptolemos had hero-cult in Delphi already in the Classical period rests on the dismissal of Pausanias' statement of a 3rd-century introduction of the cult as a misunderstanding. If Pausanias got it wrong here, can we really trust all his other information without discussing it? The same goes for sources like Lucian or Johannes Lydos, not to mention the scholia, which figure prominently. One concept frequently referred to is the notion of 'popular belief, which is used to explain what kind of religious sentiment we may encounter in the sources. It would have been interesting to have this notion defined, considering the often selective and elitist nature of many ancient authors.

Finally, if we are to assume that heroization of ordinary persons, after death and sometimes even in lifetime, was a fairly common event in Classical Greek society, we have to consider the contents of this cult. What kind of ritual was performed for these heroes, the same kind as for the gods and mythic or epic heroes, that is thysiai with animal sacrifice, or was the cult more like the cult of the dead? If the religious attention paid to them did not contain animal sacrifice, can we label it a 'hero-cult' or 'heroic honours'? These are highly complex issues and C. has made it easy for himself by avoiding them by simply speaking of 'hero-cult', 'cult' or 'heroization' without really addressing the topic of the ritual content or the religious consequences of his extension of the practice of heroization in the Classical period.

To conclude, any study, which questions traditional scholarly notions of what went on in Greek religion, is refreshing. Hero-cults, and its different facets, have always been a difficult item to digest and understand for modern scholars, partly since there is no good equivalent for comparison within our Judeo-Christian culture (the saints being fundamentally different from the Greek heroes). C.'s study has certainly opened up new ways of thinking about both the purpose and the institution of hero-cults, which will hopefully stimulate yet further work on Greek heroes.

Gunnel Ekroth

(University of Stockholm)

PARKER Robert, Polytheism and Society at Athens, Oxford, Oxford University Press, 2005. 1 vol. $14 \times 22 \mathrm{~cm}$, XxxII+544 p. (Oxford Classical Monographs). ISBN : 0-19-927483-5.

En 1996, R. Parker (R.P.) publiait Athenian Religion. A History, un ouvrage qui tentait le pari difficile d'inscrire les manifestations de la vie religieuse athénienne dans une perspective chronologique qui en identifie les évolutions et les changements. Le pari était réussi, mais il avait un prix : la mise à l'écart d'un traitement circonstancié d'éléments essentiels de cette vie religieuse dont la dimension historique, au sens chronologique du terme, peinait à rendre compte. On attendait donc la suite... Elle est arrivée sous la forme d'un fort ouvrage, absolument remarquable: la connaissance approfondie de la documentation, qu'elle soit littéraire, épigraphique, archéologique ou iconographique, et le traitement adéquatement critique d'une bibliographie vraiment internationale s'y soutiennent et interagissent pour fournir une synthèse qui fera date, tant pour les dossiers qui s'y déploient que pour les questionnements précis et la méthode pragmatique ${ }^{1}$ qui en structurent l'analyse.

${ }^{1}$ Je transpose ainsi ce que R.P. appelle, à la page 222, « a measure of everyday canniness and caution »... 